\title{
The Framing of Abortion in the Czech Republic: How the Continuity of Discourse Prevents Institutional Change*
}

\author{
RADKA DUDOVÁ** \\ Leiden University
}

\begin{abstract}
Abortion was first legalised in Czechoslovakia at a relatively early date - in 1957. However, unlike in Western Europe, this did not occur as a result of pressure from civil society and the feminist movement. While attempting to explain the continuity and change of abortion institutions in the former Czechoslovakia /Czech Republic, the article focuses on the framing of the debates that preceded the changes in abortion legislation in the Czech Republic since the 1950s. Discourse analysis of media and expert articles, parliamentary debates, and other documents shows that abortion in the Czech Republic was framed as a medical issue since the 1950s, not an issue of women's rights or bodily citizenship. Gynaecologists were the most important actors in the abortion debates. The effect of this medicalised discourse of abortion was the construction of a specific knowledge on abortion. In spite of existing alternative discourses, this original discourse now hinders the possibility of reframing abortion in terms of women's reproductive rights and this is reflected in the status quo of the abortion legislation. The continuity of dominant discourse therefore reflects and reinforces the path-dependency of the institutions.
\end{abstract}

Keywords: abortion policy, body discourse, frame analysis, discursive institutionalism, Czech Republic

Sociologický časopis/Czech Sociological Review, 2010, Vol. 46, No. 6: 945-975

\section{Introduction}

The right to legal and safe abortion was without doubt one of the key points in the campaigns of women's movements in the 1960s and the 1970s. The possibility to make decisions about one's body was an important demand of second-wave feminism in Western Europe and the United States, and these debates and conflicts over women's access abortion led to a redefinition of women's autonomy and freedom, reproductive rights, and motherhood.

\footnotetext{
* This text was prepared with the support of the FEMCIT project (Gendered Citizenship in Multicultural Europe: The Impact of Contemporary Women's Movements), financed by the 6th EU Framework Programme, Priority 7, Networks of Excellence and Integrated Projects: Citizens and Governance in a Knowledge-based Society, 2007-2011 (i.n. 028746).

** Direct all correspondence to: Radka Dudová, Institute of Political Sciences, Leiden University, Wassenaarseweg 52, 2333 AK Leiden, Netherlands, e-mail: radka.dudova@soc.cas. cz.
} 
In the Central and Eastern European bloc (and in the USSR), the history of 'abortion politics' followed a different path. Since the first debates preceding the legalisation of abortion on social grounds in 1957, abortion was framed in different terms in Czechoslovakia, although some similarities with other European countries can be found.

Below, I intend to analyse the framing of the debates that preceded the changes in abortion legislation since the 1950s, in order to explain the continuity and change of abortion institutions in the former Czechoslovakia and now Czech Republic. My article aims to contribute to the existing literature on the politics, discourses, and practices of abortion in the countries of Eastern and Central Europe - described by some as countries having an 'abortion culture' - in the second half of the 20th century [see Mureşan 2008: 426]. While literature on some countries - namely Poland, where the situation has always been rather specific - exists [see Heinen and Matuchniak-Krasuska 1995; Fuszara 2005; Heinen and Portet 2010], little was researched and written on others, including Czechoslovakia / Czech Republic.

I am interested, from the sociological point of view, in the ways in which abortion was constructed in the public (media, expert, and political) discourse and how it was framed by different actors, and how this construction influenced institutional change and also further thought and discussion of abortion. Therefore, my article aims to contribute to the current debate on the role of the ideas and discourses in the process of change of institutions [see, e.g., Rothstein 2005; Kulawik 2009; Schmidt 2010].

By demonstrating the historical continuity of the dominant discourse, I aim to explain the stability of the current abortion legislation in the Czech Republic. Since the 1950s, when abortion was widely legalised for the first time, the issue of abortion was represented through a medical expert discourse (produced and presented by medical experts using medical arguments) that corresponds to the Foucauldian complex of power/knowledge. Despite the fact that alternative discourses exist, this original discourse now hinders the reframing of abortion in terms of women's reproductive rights and this is reflected in the status quo of Czech abortion legislation. The continuity of this dominant discourse therefore reflects and reinforces the path-dependency of the relevant institutions.

To demonstrate this continuity, I first introduce the analytic framework of discursive institutionalism and the theory of discourse as a locus of the constitution of knowledge, inescapably tied to power relations, and then I describe the methodology of discourse analysis that I am using in my research. Then I present three important debates on abortion that since 1955 have taken place in the former Czechoslovakia / Czech Republic and show how the frames that were used are mirrored in the current situation and in discussions. 


\section{Theory}

Historical institutionalism, a social-science approach that analyses institutions in order to find sequences of social, political, and economic behaviour across time and is widely used in political science and sociology, has been criticised for being incapable of adequately accounting for change [see, e.g., Peters, Jon and King 2005: 1277]. According to Vivien Schmidt [2010: 2], this method has been better at explaining continuity than change. Discursive institutionalism, a new analytic framework, aims to overcome this limitation by introducing the role of ideas and/or discourse in explanations of institutional change. Institutions should not be treated as neutral structures of incentives 'but, rather, as the carriers of ideas which make them objects of trust or mistrust and changeable over time as actors' ideas and discourse about them change' [Rothstein 2005: 168-198]. 'How ideas are generated among policy actors and communicated to the public by political actors through discourse is the key to explaining institutional change (and continuity)' [Schmidt 2010: 15]. According to Teresa Kulawik [2009: 268-269], institutions are constituted by discursive struggles and can be understood as sedimented discourses. Moreover, the expert knowledge plays a special role in the national discourses of all modern states. Thus, it makes sense to focus on the discourses and framing of abortion when attempting to explain the continuity and change of abortion institutions in the former Czechoslovakia / the Czech Republic.

According to Michel Foucault [1994, 2004], discourse is an argued dialogue within a culture, a procedure that formulates beforehand what our knowledge can discuss, what it can say and do. As such it is hegemonic in character. According to the early works of Foucault, there is neither any sort of underlying meaning or truth within things, nor any transcendental meaning or truth to be imposed upon things. Knowledge is then a 'product' - the production of human communication. It occurs only inside the validating, material framework of a larger pattern of discourse [Schneck 1987: 18]. Foucault [1961, 1963] shows how the contemporary discourse of modernity reflects the realities of dominance and repression in current relations of power. The power relations are pervasive in the broader pattern of discourse; knowledge claims are part of both the pattern of discourse and the relations of power: 'truth isn't outside power, or lacking in power' (...). Truth is a thing of this world: it is produced only by virtue of multiple forms of constraint. And it induces regular effects of power' [Foucault 1980: 131]. To know is not to discover truth, but to make the truth - and in every society and period, there are different 'regimes of truth' (mechanisms and instances producing truth, means by which it is sanctioned, and actors who are charged with saying what counts as true [Foucault 1980: 131].

According to Norman Fairclough [1992: 28], discourse can be defined as 'language in use, whether speech or writing, seen as a type of social practice'. Discourse is language use relative to social, political, and cultural formations - it is language reflecting social order, but also language shaping social order, and shaping individuals' interaction with society. Discourse practices can therefore 
be seen as the deployment of, and indeed sometimes as acts of, resistance to dominant ideologies.

I define discourse as a social dialogue that takes place through and across societal institutions, among individuals as well as groups, organisations, and political institutions. Critical discourse analysis is then concerned with discourse as the instrument of the social construction of reality [van Leeuwen 1993: 193]. All people define situations as real, but when powerful people define situations as real, then they are real for everybody involved in their consequences [Mehan 1999: 537]. The reproduction of power relations and dominance depends then also on the structures of discourse: who is allowed (or obliged) to speak or listen to whom, how, about what, when and where and with what consequences [van Dijk 1993: 110].

Data and information in the discourse are grouped together under the heading of one subsuming category, a larger 'frame' which provides them with a recognisable structure and meaning. These categories, or frames, by means of which people 'perceive' the world, are categories which are already present in the perceiver's culture or memory. The frames then work as guiding models for what is to be understood in the discourse. Once a frame is elicited, data or elements that do not fit well will be adapted or selectively excluded. Framing is understood as the activity of selecting some aspects of a perceived reality and make them more salient in a communicating text in such a way as to promote a particular problem definition, causal interpretation, moral evaluation, and/or treatment recommendation [Entman 1993: 52].

Policy debates emerge out of certain discourses and thus they have certain frames; these can be identified and described. Social movements have their own frames that can correspond or not to the frames of policymakers. According to Snow and Benford [1988: 198], movements are carriers of beliefs and ideologies. In addition, they are part of the process of constructing meaning for participants and opponents. Mass movements are said to be successful when the frames projected align with the frames of the participants to produce resonance between the two parties. This is a process known as 'frame alignment'. In the research on abortion policies in Czechoslovakia / the Czech Republic, I analyse both the policy frames and the social movement frames, as both groups of actors took part in constituting abortion policies.

\section{Methodology}

My aim here is to reveal the discourse that has accompanied the process of abortion legalisation in Czechoslovakia / the Czech Republic since 1955 and to show how abortion - and women requesting an abortion - was framed in this discourse and what impact this framing had on the actual politics of abortion. In order to do this, I use the approach described by Paolo R. Donati [1992] as political discourse 
analysis (inspired also by Snow and Benford's framing analysis). This consists of the following steps:

1. Topic selection and definition: choosing a social or political issue. The social issue I research is bodily citizenship [see Lister 1997: 71, 128, 201], and the object that is framed in the discussions is abortion.

2. Texts selection: the selected texts represent relevant voices in the given discourse. I analyse documents relating to abortion, with a special focus on the four main public debates $(1957,1986,2003$, and 2008). I focus on the period from the mid-1950s (when abortion for other than health grounds alone was legalised for the first time) to the present day. These specific debates are significant because they mark moments of important legislation change, or an attempt at such change, in the post-war history of the Czech Republic.

The documents I gathered were divided into the following groups or 'families': laws and legal regulations; parliamentary debates; newspaper and journal articles; interviews; social science articles (demographic, sociological, and psychological); gynaecologists' materials and articles; materials from feminist and women's groups and from anti-abortion groups.

In order to capture the public (media) discourse, I analysed in detail the magazine Vlasta $^{1}$ (the contents of issues published between 1948 and 1973 and between 1983 and 1986, and I collected all articles dealing with the issue of abortion. I also included a debate that took place on the pages of Literární noviny (Literary News, a weekly periodical focusing on cultural events and philosophical issues) in July-September 1957 after mention of the intention to legalise abortion was published there. For expert articles I analysed the journal Československá gynekologie (Czechoslovak Gynaecology), the leading gynaecology and obstetrics journal published in the period of state-socialism (I analysed issues published in 19561958 and 1970-1986), and some scholarly monographs. I also analysed the journal Demografie (Demography), the leading journal on demography in the country (I analysed issues published in 1957-2009). For the 1990-2009 period, I analysed the on-line editions of the main Czech newspapers (IDnes, Lidové noviny, Ceské noviny), where possible to conduct full-text searches. I also included press statements made by the key actors. Parliamentary debates were analysed in detail using the digitised and on-line database of the Parliament of the Czech Republic. Limitations to this approach stem from the fact that (in the state-socialist period)

\footnotetext{
${ }^{1}$ Vlasta was originally edited by the Council of Czechoslovak Women, a women's organisation that claimed the legacy of pre-war women's organisations. After the communist putsch in 1948, the communist Committee of Czechoslovak Women, the only official women's organisation, got hold of the magazine. Throughout the 1950s-1980s it was published in a massive edition; with a print run of 660000 copies Vlasta was the second most-read periodical after Rudé právo [Jechová 2008: 89]. The magazine obviously followed the politics and ideology of the ruling party; nonetheless, it was on the pages of Vlasta that discussion of some of the smaller issues troubling women and requiring solutions was opened up.
} 
the public discussion was mediated by official propaganda - i.e. not all the voices that may have existed was allowed to be expressed. For this reason, I supplemented the analysis of pre-1989 documents with secondary (mainly historical) literature published after 1989 and with interviews conducted with witnesses and contemporaries of the analysed events.

3. Frames: according to Donati [1992: 151], the name of the frame should be something that really makes sense to the receiver, a well-known construct that the receiver will use to orientate his/her perception. It is a cultural construct which is included in the receiver's cultural tools and knowledge.

In order to identify the frames, I conducted the text analysis as follows: With the assistance of the computer program Atlas.ti, I identified the individual arguments used in the texts, then coded and grouped them into categories through comparisons on multiple levels (intratextual and intertextual comparisons, comparisons of different families of texts, comparisons of texts by different authors, etc.), until several 'systems' of argumentation emerged. After having identified the frames, I specified the each respective frame's main characteristics and arguments, focusing special attention on the place of women in the discourse. I explained who used the frame and what means were employed to present and communicate the frame, and I paid special attention to women's and feminist movement's frames and discourses of abortion.

\section{Development of the issue}

In comparison to European countries in the West, abortion was legalised in Czechoslovakia early, almost as soon as the situation in the stormy years after the Second World War more or less calmed down. Unlike in Western Europe, however, this did not occur as a result of pressure from civil society and the feminist movement, but was rather a bureaucratic decision that arose out of macro-social and political circumstances.

In 1955 abortion on demand was legalised in the USSR and in the following year also in other Eastern European countries - Bulgaria, Hungary, and Poland. According to some indications, the legalisation of abortion in Czechoslovakia in 1957 was part of a wider project inspired by a political decision made in the USSR. The authorities were undoubtedly inspired by this wave of legalisation. Nevertheless, other social and political circumstances also played a role. ${ }^{2}$

2 According to Milada Bartošová (in an interview on 10 June 2009), the submission of the first abortion law was a logical follow-up to the efforts of women who had been trying to push through the liberalisation of abortion already in the interwar period. It was the result of the joint efforts of several communist women - Members of Parliament (e.g. Zdenka Patschová) - and experts - gynaecologists (mainly Miroslav Vojta).

According to the demographer Vladimír Kučera (in an interview on 8 June 2009), the Soviet model was a very important impulse to the preparation of the law, and Czecho- 
The socioeconomic situation in Czechoslovakia at the end of the 1950s was not very good and a shortage of basic products had endured since the end of the war. The inability to improve this situation proved to be one of the first signs of the inefficiency of the planned economy. In this context, access to abortion was viewed by government actors as another form of welfare policy (according to Vladimír Kučera in an interview dated 8 June 2009; see Footnote 3). Conversely, the demographic situation of the country was rather good and was characterised by population growth.

Until 1957, abortion was illegal in the Czech Republic. The penal code adopted in 1950 allowed for medical abortion under certain conditions, but otherwise any abortion was qualified as the killing of a human foetus punishable by imprisonment. In 1957 the Act on the Artificial Termination of Pregnancy (No. 68/1957) was passed. The text of the law was prepared by a group of experts, one of whom was Senta Radvanová (a young lawyer who later cooperated with the Czech Union of Women and who participated in the preparation of all important legislation on women and the family). One of the leading experts was Miroslav Vojta, the main state expert on gynaecology and obstetrics.

The new act legalised abortion under specific conditions (special commissions decided whether to authorise an abortion requested by a pregnant woman, either for health reasons or for 'other important reasons', including social indications). The decision to terminate an unwanted pregnancy was thus not placed directly in the hands of women, but rather was subject to authorisation from official commissions. These commissions did not function just as advisory bodies, offering women assistance and support; they had the power to make the final decision about the reproductive rights of each individual woman.

Over the next thirty years the legislation did not change significantly, although it was repeatedly amended by orders and regulations issued by the Ministry of Health, according to the demographic and economic situation of the country.

slovakia was one of the last countries where abortion was outlawed. At the same time he confirms the active role of some communist women - MPs who intended to 'revolutionise the family' by defamilising care services and giving women the right to make decisions about their pregnancy. Nonetheless, this argument was not used in the discussions.

Dr. Milada Bartošová graduated as a sociologist from Charles University in 1947, and in 1969 she defended her dissertation on women's and feminist movements in Czechoslovakia between 1945 and 1948. Meanwhile she worked in the Czechoslovak Statistical Office and collaborated closely with the Czech Union of Women. After 1969, she worked for several years as consultant to the head of the Czech Union of Women Gusta Fučíková.

Dr. Vladimír Kučera worked from the early 1950s in the Czechoslovak Statistical Office as a demographer. He participated in the first large quantitative survey of family and reproduction in 1956, which served as the basis for the preparation of the abortion law. Later his work concentrated mainly on the Population and Household Census conducted every ten years. He is from a Protestant background. 
The period of building socialism and early collectivist ideas drew to a close at the start of the 1960s. After years of economic stagnation and decline, a project of economic reform was developed. In the sphere of ideas, room opened up for the exchange of ideas through the media and public discussions on various themes got under way. The period between 1968 and 1969 was a time of important upheaval in civil society, including the women's movement. The reform process that was partly initiated by Communist Party representatives' attempts to build 'socialism with human face' led to a more relaxed atmosphere in every sphere of social life, but this came to a halt with the invasion of Warsaw Pact troops in August 1968. Although civil society tried to resist the imposed return of the totalitarian regime, by June 1969 the personnel of all important institutions had been replaced with new people compliant with the new orientation of the Party and all media were censored again [Kalinová 1999: 15].

The regulation of abortion was tightened in 1973 to conform to the stricter atmosphere of the 'normalisation' period (as the time after the tumultuous events of 1968 was called) and to the application of several pro-populationist measures that were introduced. The new political establishment after 1969 tried to provide some compensation and especially to win over the younger generation. A social programme that was prepared by experts back in 1966 [see Wolchik 2000: 63-64; Kalinová 1999: 23] was used for this purpose. Key features were care for families and assistance to young newlyweds. Recommendations were issued that abortion commissions be stricter in their decisions, especially in the case of women without children or with just one child and requesting an abortion for social reasons. This move was substantiated in the media as a measure to improve population development and population quality, which was in the interest of 'the Party and the government' [Zajíček 1973: 20].

Stricter abortion regulation and (more) social benefits for parents led to an increase of the birth rate and simultaneously to a decrease in the abortion rate (from 71893 induced abortions in 1970 in Czech Republic ${ }^{3}$ to 55511 in 1975; ÚZIS [2008]). Nonetheless, at the end of the 1970s the abortion rate began to rise again given that contraception was not widely available and often ineffective. In the 1980s discussion of possible reform began. As we shall see below, the debate was led mainly by experts in the field of gynaecology and obstetrics, psychology and psychiatry, and demography.

The gynaecologist Jiří Šráček was one of the people who had a decisive impact on amending the law and bringing about the abandonment of abortion commissions. ${ }^{4}$ According to Šráček, he and his friend and fellow gynaecologist

\footnotetext{
${ }^{3}$ Data split for the Czech and the Slovak Republic.

${ }^{4}$ Jiř́ Šráček was a gynaecologist and obstetrician born in 1925. In 1972 he became chief of the Department of Gynaecology and Obstetrics at the hospital in Ostrava. He was one of the main experts in gynaecology and obstetrics and a member of the Communist party. He promoted contraception in the Czech Republic and helped to improve it and make it accessible within the conditions of the planned economy (he managed to get better quality
} 
R. Winniczuk lobbied Čestmír Adam, the director of the Social and Health Committee of Parliament and deputy chair of Parliament (Czech National Council). Adam was the former schoolmate and friend of Winniczuk. Šráček also exercised his influence on the issue as a member of the Governmental Population Commission, where he acted as the expert for family planning (Šráček in an interview conducted on 19 June 2009).

The Governmental Population Commission had in fact quite extensive authority and power to propose new legislation. The commission was compromised of deputy ministers and representatives of organisations in society - union organisations, the Union of Youth, or the Union of Women. It also included experts from research institutes. The task of the commission was to provide the government with materials, make policy recommendations, and oversee their implementation. The Commission also assigned research institutes with the themes that needed to be addressed [Heitlinger 1984; Kalinová 1999: 24]. The Population Commission collaborated closely with abortion commissions and was supposed to issue recommendations concerning abortion policies. Its position on abortion regulation was more pro-choice, although some of the medical experts on the Commission were more conservative (such as the Czech state's Chief Gynaecologist Alfred Kotásek). The Governmental Population Commission, Čestmír Adam and his parliamentary Social and Health Committee, and the Ministry of Health and its minister Jaroslav Prokopec were the main actors advocating for the new legislation to pass.

Still, it took several years to prepare the legislative amendment and a few more before it was passed. According to the demographer Ludmila Fialová (in an interview conducted 16 December 2008) the amendment was ready in 1982, but had to wait until it gained the support of all the authorities, specifically the Slovak part of Parliament. The costs of the changes included in the law also represented a problem - contraception and mini-abortions were to be provided for free and covered by the National Health Insurance. Nevertheless, the consensus that the law must be changed and the abortion commissions abolished finally prevailed.

As a result of these debates, Act No. 66/1986 Coll. on the induced termination of pregnancy took effect on July 1987. From that time abortion was granted on written demand from a pregnant woman as long as the duration of the pregnancy was no longer than 12 weeks. This legislation still applies today.

The period since 1989 has been marked by recurring discussions on the moral acceptability or unacceptability of abortion. On one hand, opponents of free choice regard the current abortion law as a communist law and unrestricted

condoms imported from the West and have better-quality condoms produced in the Czech Republic, and he adapted the intra-uterine device and managed it have it produced in the Czech Republic - he named the Czech IUD after his wife DANA, and this name is still used colloquially to refer to contemporary IUDs). 
access to abortion as a negative remnant from the communist regime. While before 1989 Christian-minded Members of Parliament ${ }^{5}$ could not openly present their opinions and were not allowed to vote against the laws proposed in Parliament (in practice they would leave the hall of Parliament when such laws were voted for), after 1989 they started to form a serious political power.

On the other hand, some experts and representatives of the feminist movement claim that Act No. 66/1986 should be amended because it has several shortcomings owing to the absence of democratic discussion in the period when the law was being prepared. In 1991, a group of experts headed by Jiř́ Šráček started to work on amending the wording of the abortion law. They aimed mainly to reduce state control over the performance of abortion and to widen women's access to induced abortion. Submission of this law to the Government was finally blocked by the then Prime Minister Václav Klaus from the right-wing Civic Democratic Party (ODS), which was ruling in a coalition with the Christian Democratic Party (KDU-ČSL), a ferocious opponent of abortion.

In 2003, a group of conservative Members of Parliament - Jiří Karas (KDU-ČSL), Jan Kasal (KDU-CSL) and Petr Pleva (ODS) - proposed a law that would make abortion illegal. This bill was rejected in the first reading (on 30 March 2004), but the discussion that accompanied it in Parliament and in the media showed the disagreement and conflicting opinions of different actors on the issue.

After the debacle of 2004, the abortion debates subsided for several years, with no initiative to restart them on either of the two sides. The discussion was only re-opened in 2008 when, on the one hand, the government introduced a bill on specific health services ${ }^{6}$ as a part of general health reform, and on the other hand, Christian-Democrats published demands to restrict abortion rights. Despite the passionate debates that took place in 2004 and again in 2008 Czech abortion legislation was not changed.

Below, I will present the debates that preceded the legislative changes in 1957 and 1986 and the debates that took place in the post-communist period. I will show the main frames of the dominant public discourse and each frame's main characteristics and arguments, with special attention to the place of women in the discourse.

\footnotetext{
5 This refers mainly to Roman Catholics, as the Protestant denominations took a more compromising position towards artificial abortion (Kučera, in an interview dated 8 June 2009).

6 The proposed legislation 'on specific health services' copied its main features from the previous law of 1986 (keeping the time limit of 12 weeks for abortion on demand and 24 weeks in cases where the foetus has genetic defects). Nonetheless, there were several points that would in practice mean a widening of access to abortion.
} 


\section{Debate 1957: 'legal abortion as a way to healthier motherhood'}

In the pre-war debates, the abortion issue was addressed and brought up in Parliament by women MPs active in the first wave of the women's movement, and consequently it was framed in terms of a woman's right to choose [see Musilová 2007]. After the communist coup d'état, feminist groups were dismantled and could not play the role of agenda-setter. In the public discussion leading up to the adoption of Act No. 69/1957 on Induced Termination of Pregnancy, the main actors were doctors, primarily gynaecologists, and mostly medical arguments were used. The frame that they asserted and that became dominant in the subsequent debate can be called 'legal abortion as way to healthier motherhood'. The premise was that the number of abortions was high regardless of the restrictive law and the abortions were being performed by unskilled people in inappropriate conditions. Poor hygiene and the absence of professional expertise meant that abortions had very negative consequences for women's health, ranging from immediate symptoms (bleeding, inflammations) that had to be cured in public hospitals, to long-term effects, typically infertility (in 75\% of cases, according to Slunský [1957]), frigidity, and psychical complaints [Hnátek 1957; Vojta 1957]. Infertility as a consequence of an abortion was the most important and widely used argument - mainly with regard to women who had not yet had children. ${ }^{7}$

From the start of the discussions, it was made clear that hospital abortions presented a serious risk as well, but much less so than illegal ones. This served as the reason for not liberalising abortion completely. As (some) women could abuse the legalisation of abortion and ignore the still existing health risks, it was argued, there must be some control mechanism that could judge the legitimacy of the demand and limit the final number of performed abortions. This mechanism was to be constituted by the abortion commission.

\section{The position of women in the discourse}

Were we to believe the media from this period, the typical woman who underwent an illegal abortion was a mother of five, with an alcoholic husband who did not support the family sufficiently and forced the woman to have sex. The woman then found herself pregnant and, in order to be able to take care of her children, had to turn to an unskilled 'angel-maker' who would rid her of the pregnancy while causing irreparable damage to her health. A possible variation was an unmarried woman with a child receiving no support from the father and struggling

\footnotetext{
${ }^{7}$ It is interesting to note that the negative health consequences of abortions were explored in the cases of women who presented themselves at the hospital with some kind of complications after having an abortion. According to an article by Dr. Miroslav Vojta [1961], it was discovered later that these were mainly women who experienced a spontaneous abortion, not women who had had an illegal abortion, as was assumed.
} 
in poverty. Here are examples how these women were presented in the articles in Literární noviny in 1957:

A few weeks ago, the People's Court in Prague dealt with this case: A mother of five children decided to terminate her pregnancy. Her husband was a drunkard, he did not care for the children. An angel-maker performed the surgery. Unprofessionally, violating all the basic hygiene rules, and the woman got sepsis and died a few days later. [Radvanová, Nezkusil and Novotný 1957]

Men usually do not care for their illegitimate children. There are cases of men who have more than one of illegitimate children. Women struggle to obtain some alimony for their children. All the difficulties of care and support of children thus are borne by women. [Mikule 1957]

These women, according to the articles published in Czech journals in the late 1950s, should be given the option to terminate their pregnancy - but should not decide just by themselves. Seeking an abortion was still sometimes considered 'a display of egoism, frivolousness and a misunderstanding of life' [Radvanová, Nezkusil and Novotný 1957] on the part of women. Even though later articles assumed that these cases of 'selfish requests for abortion may be just the minority ['Na závěr diskuse' 1957], they still had to be subject to the decision of abortion commissions. With some exceptions, women were usually portrayed as unselfish beings sacrificing their own well-being (i.e. having a baby ${ }^{8}$ ) for the well-being of the others (other children, family) or as victims of unscrupulous men (and sometimes both simultaneously). Those women who asked for an abortion for 'selfish' reasons were to be educated and their morals improved.

Experts and authorities thus took this patronising view of all women without exception, seen as either irresponsible or extremely vulnerable, and called to their responsibilities towards their family and the socialist society. The fact that men might also have some role in the act of conception was mentioned only by the rare opponents of the legalisation of abortion, and only indirectly:

But I think that the majority of women who seek illegal abortion are not passive victims but rather bear half the responsibility for the resulting pregnancy. [Štěpánek 1957]

The legalisation of abortion was paradoxically interpreted as a pro-population measure: the reproductive health of women would be saved by hospital-performed abortions, so those women would be able to have children later in life. It

${ }^{8}$ For example, in an article in Vlasta Anna Tučková [1957] wrote: 'A child means happiness. And a child with a beloved person is probably the greatest happiness a woman can experience.' 
was assumed that the number of legal abortions would not exceed the number of illegal abortions performed, and that in the course of time the reasons that led women to opt for an abortion would disappear as society would be able to react to and relieve them.

Legal and safe abortion was thus considered to be legitimate for women in difficult social situations that prevented them from caring properly for their children. Women could get an abortion not in order to avoid becoming mothers, but in order to be better mothers. From the start of the discussions, it was somehow assumed that women could 'abuse' the new law. They were therefore repeatedly reminded that even a hospital abortion could have negative health consequences: that by undergoing an abortion, they were running the important risk of not being able to have children in the future.

\section{By whom and where was the frame used?}

'Legal abortion as way to healthier motherhood' was the frame first of all used by gynaecologists and other doctors. The role of medical experts in the public and political debates was also crucial in the issue's subsequent development. In fact, throughout the communist period gynaecologists were the most visible advocates of legal abortion in public. They set the agenda, they pushed the issue forward, and at the same time they kept control over the issue. The attitudes of individual doctors were of course not homogenous. There were 'progressive' doctors who advocated for legalisation, with the cooperation and support of leading authorities of the Party (such as Miroslav Vojta, editor of Československá gynekologie, and the state's main expert on gynaecology and obstetrics), and who also maximised their efforts to make effective contraception widely accessible (like Ladislav Hnátek, who in 1957 opened the first planned parenthood advisory office in Prague). There were also more conservative doctors (possibly from a Catholic background) who doubted the benefits of legal abortion (like Jiř́ Štěpánek) and sometimes refused to perform an abortion after the law came into effect. The debate was carried on in medical terms, using the health of women as the main argument on both sides. Gynaecologists spoke from the position of authority and knowledge, while women asking for an abortion were to be judged by a commission, educated, and helped.

The medical discourse was then adopted by lawmakers. The authors of an article that appeared in Literární noviny in July 1957, lawyers Senta Radvanová, Jiří Nezkusil and Oto Novotný (who were involved in drafting the law), argued: 'Every abortion poses some risks for the woman. We must take this into account. The aim is to find a solution that will do as little damage as possible.' This article then initiated a discussion on the pages of Literární noviny.

The frame of 'healthier motherhood' was used also by speakers in the parliamentary debate over Act No. 68/1957: '...criminal law (...) drives pregnant 
women in the hands of bunglers and horse doctors, who by force of unskilled and unhygienic interventions induce serious injuries on the health of our women' (MP Věra Štastná, reporter of the Health and Constitutional Committee, debate in the National Assembly on 19 December 1957, 10:53).

\section{Frame alignment and frame resonance}

The 'healthier motherhood' frame resonated strongly with other frames that our analysis identified in the contemporary media, in particular the 'population discourse' advanced by demographers, planners, and politicians. This discourse was present in the media and its arguments backed up the arguments of the 'healthier motherhood' frame. In the process, the two frames aligned and merged, stressing the importance of the legalisation of abortion in order to have healthier mothers, healthier children, and, as a consequence, a healthier population.

The 'population discourse' encompassed concerns both about quantity and quality. It was assumed that if the law were correctly interpreted and applied, not only would it improve the quality of the population (as women would have only those children they would be able to care for properly), but in the end it would also lead to further population growth, as safe abortions would improve the reproductive health of women.

The argument that is central to the later discourse of anti-pro-choice groups - the argument of the immoral killing of the 'unborn child' - appeared in the newspapers only once and was cited by Jiři Štěpánek in his article opposing the proposed legalisation of abortion. This might be due to the fact that communist censorship did everything to prevent any such ideas appearing in the media. It is no surprise that the 'discussion' was limited to the canvassing of 'progressive' opinion by the Party-state authorities among professionals known to be in favour of legalising abortion. Some opponents were allowed to express their opinion, but since the public debates, and possibly also 'private' ones among professionals, were controlled and censored, we have no way of knowing how rare views opposed to the legalisation of abortion actually were. The position of the Catholic Church in state-socialist Czechoslovakia was very weak (especially in comparison to Poland) and its influence on public events was only indirect (e.g. through some experts or journalists who were members of the 'underground' Church). The Czech population's relationship with the church was rather ambiguous even before the onset of communism, and in the second half of the 20th century public indifference towards church religion was deepened by the communist regime's anti-religious propaganda and persecution (of the church) [Hamplová 2010].

The framing of abortion in terms of 'killing an unborn baby', which is a frame peculiar to the groups and actors that oppose a woman's right to abortion, such as the Catholic Church and different 'pro-life' organisations, did not appear in public texts. As a consequence, the legalisation of abortion was not constructed 
as a controversial moral issue, putting the rights of the mother against the rights of the foetus, as occurred in other countries.

The dominant discourse of abortion in Czechoslovakia in the late 1950s, that is, when the first law to legalise abortion was being developed and was passed, was in fact the discourse of motherhood. The proclaimed aim of the abortion legalisation was to enable women to be better mothers: to protect their reproductive health, which could be harmed by an illegal abortion or many successive births, and allow them to be better able to choose the time to have children so that they have the necessary material and psychological resources to be a mother, and thus to produce a better-quality population. Women seeking abortions were portrayed as mothers: typically such a woman was already the mother of several children, whose well-being would be threatened if another child were born. Abortion was therefore not presented as a means of women's emancipation (even though some minor voices tried to put it this way); it served rather to tighten the link between womanhood and motherhood and bound women even more strongly to their 'natural vocation' of mothering [see also Fidelis 2008: 205-206].

How this frame related to official communist ideology is unclear. As Mary Buckley notes [1989], a commitment in theory to women's rights was part of Marxism-Leninism from the beginning. But throughout its history, ideology and economic necessity have intertwined, with the latter usually driving the former. Maxine Molyneux [1981] speaks of the 'selective canonisation' of the works of Marx and Engels, which resulted in the very limited notions of women's emancipation during the state-socialist period. Women were to be emancipated primarily through their participation in the labour market and their liberation from the constraints of the traditional social order. This configuration did not provide any real space for developing notions of gender equality in the private sphere, in the family and reproduction.

\section{The debates in 1979-1986: safer abortion and the suffering of unwanted children}

In the 1980s the practice of the abortion commissions became untenable and possible reform started to be discussed. By the end of the 1970s the commissions were already facing a considerable amount of criticism. This was due to two important events: (1) the invention and diffusion in Czechoslovakia of the method of menstrual regulation known as the 'mini-abortion'; and (2) a psychological study of unwanted children by Dytrych, Matějček and Schüller [1975] revealing the psychological damage of unwanted pregnancy on children born out of these pregnancies. In consequence, there were two main frames in the debates that preceded the approval of Act No. 66/1986. Although they came from different backgrounds and their arguments were different, they influenced and reinforced each other. 


\section{The 'all children have the right to be born wanted' frame}

After a study conducted in Prague by researchers at the Research Institute of Psychiatry [see Dytrych et al. 1975] ${ }^{9}$ revealed the negative psychological consequences of unwanted pregnancy for the well-being of children born out of these pregnancies, abortion was considered the best solution in the case of an unwanted pregnancy. It was therefore argued that it would be better for unwanted children not to be born and abortion was in their best interest. The results of the research were published in the Slovak journal Psychologia a patopsychologia dietata (Child Psychology and Pathopsychology) and Demografie in 1974-1976 and were widely popularised (e.g. they were the topic of a programme on Czech Television channel 2 on 19 May 1978; see also Birgus [1979: 71]). The interest of these children was presented together with the best interest of society (which was now equated with a healthy and quality population). For example, in an article published in 1979, Jan Birgus (who in 1977 was still advocating that commissions be stricter about abortion) considered abortion the preferred solution for avoiding the 'risk of pathological personality development in the unwanted child and the threat that represents to the quality of our population' [Birgus 1979: 70].

The best interest of the society was also extensively cited by the psychologist Drahomíra Fukalová [1979]. She stated that the decision-making of the abortion commissions had to follow the interest of society as a whole. It is in the best interest of the state and society to terminate some pregnancies - those where the mother would not accept the child and the child would suffer from being born as unwanted.

From her perspective as a psychologist, she attempted to show that the prevailing assumption that the mother would always finally accept and love her child once it was born was just a part of the taboo of negative maternal conduct

\footnotetext{
9 The study was a unique project that influenced the thinking about abortion in the former Czechoslovakia but also across its borders. Since applications for abortion in the former Czechoslovakia were not automatically approved, it was possible to study a group of children born to mothers who had been denied abortions for the same foetus on two separate occasions - first at the district abortion commission and then after the appeal of the mother to the regional abortion commission. The researchers Z. Matějček and D. Langmaier who started the study in 1970 gained (though possibly not totally legally) access to addresses of women in Prague who were denied abortion twice. Social workers working for the study first then visited the women and interviewed them, later on their children were to find out how many children were actually born of those unwanted pregnancies. It was discovered that a significantly large share of these pregnancies ended in a spontaneous abortion anyway (the real spontaneity of these abortions may of course be questioned) and some of the pregnancies disappeared without any official record. The 220 children that were born were observed repeatedly during their life course. The control group consisted of mothers who unequivocally wanted their child. Matched pairs were based on same sex, birth order, social class, etc. The study was double-blind so neither the parents, children nor researchers knew which group was being interviewed.
} 
and that that did not happen in most cases: '(...) it is very problematic to expect that a mother will fulfil her role if she has been forced into the pregnancy' [Fukalová 1979].

\section{The 'safer abortions for women's health' frame}

The main argument of this frame, used mainly by Czech gynaecologists, was that there were several accessible means of harmless contraception, but if those failed, women must have access to safe and legal abortion, and by 'safe' they meant with as few negative health side effects as possible. The way to ensure this was with the 'mini-abortion' or early vacuum aspiration method. The proponents of this abortion method cited its merits: fewer direct complications, fewer long-term negative effects, no risks from total anaesthesia, the ability to perform the abortion on an out-patient basis, fewer personnel required, and shorter sickness leave.

The only obstacle (after special disposable aspiration curettes started to be produced in 1981) to the use of this method was in the 1957 abortion law. The proceedings of the abortion commissions were so time-consuming that the operation was often postponed until it was no longer possible to perform a mini-abortion. The solution proposed at the beginning of the 1980s was either to waive commission approval for mini-abortions or to dissolve the commissions completely. In the course of 1981, several authors called for an amendment to the 68/1957 act, in most cases so that abortion commissions would be maintained only for abortions after 6-7 weeks of pregnancy [Fukalová 1981; Havránek 1981; Štěpán 1981a, 1981b]. Some authors showed how a negative decision by an abortion commission could leave a woman in a dire situation resulting in depression or even attempted suicide [Hrádek and Petr 1981].

As one contemporary author noted: 'The complicated, time-consuming, and bureaucratic procedure [of the Abortion Commissions] leads only in a very small number of cases to an ultimate rejection of the request for an abortion. (...) [An important proportion of those refused] ended anyway in an illegal abortion. Moreover, our psychiatrists have demonstrated the socially deviant development of "unwanted" children. From this perspective, the effects of the Commissions on the improvement of our population seems problematic. For this reason we recommend (in the name of Czechoslovak Gynaecological Association) limiting the activity of these Commissions just to abortions in the late first trimester or to repealing them altogether.' [Havránek 1981]

From the texts dating from 1985 onwards it is clear that the new legislation proposed abandoning the abortion commissions. In the Memorandum accompanying the legislation it was stated that: in practice the commissions granted more than $95 \%$ of the requests from applicants; the commission proceedings are time consuming and their organisation is too demanding; the commissions do not give women in such a situation any practical assistance; and the new method of mini-abortion requires that the decision-making process be shortened. 


\section{Where were women in the discourse?}

In the discourse of gynaecologists and psychologists women were present only as objects of care, decision-making, and control, not as subjects. In the expert articles published in Československá gynekologie it was not assumed or even mentioned that a woman should have the last word in the decision about her pregnancy, nor was any space given to the consequences that an unwanted pregnancy can have for the woman (except the case study by Hrádek and Petr [1981]).

Expert discourse nevertheless evolved from the total 'objectification' and disciplining of women to the belief that women must first accept their pregnancy if later they are to care for the child properly, so a woman must not be forced into continuing the pregnancy. Nonetheless, in the expert articles we find no mention of a woman's rights or interests. At most women were treated as patients whose health and well-being must be protected by doctors.

The argument of the 'irresponsible woman' was used again in the discourse, but this time it was turned on its head by psychology experts. The fact that some women are irresponsible, unstable, or promiscuous was not a reason why they should not be given the right to decide; on the contrary, it was a reason for making abortion even more accessible to them, as they would not make proper mothers anyway. As Drahomíra Fukalová stated [1979: 752]: 'They have little predisposition to become a good mother so we should welcome the fact that they are asking for an abortion, as opposed to women who judge abortion to be damaging to their own health and carelessly breed one child after another without any notion of what the role of a mother involves.'

One important success of Fukalová's writings and the publication of the results of the Prague study was that they dismantled the myth that maternal love always comes naturally as soon as the child is born. It was shown that not all women are happy about becoming mothers and not all unwanted children are finally accepted with love and sacrifice.

\section{By whom and where was the frame used?}

As noted above, the two frames that played a major role in changing the abortion law in 1986 and abolishing abortion commissions were created by experts: gynaecologists and psychologists. They published their arguments in the form of scientific articles in gynaecology and psychology journals, namely Československá gynekologie and Psychologia a patopsychologia dietata. Their conclusions were widely disseminated in the popular media, such as Czechoslovak Television or Vlasta [see, e.g., Štěpánková 1984]. Some of them exercised their influence through the Governmental Population Commission, where they discussed the issue with the Government and Party representatives and with representatives of other organisations such as the Czechoslovak Union of Women. 


\section{Frame alignment and frame resonance}

While some gynaecology experts focused their efforts on modernising the existing abortion law, others continued to produce texts endorsing the discourse of the danger of abortion for women's health. This was in fact the most powerful counter-discourse challenging the overwhelming pro-choice orientation of society. The health risks of induced abortions had been accentuated by doctors in the media since the first abortion law in 1957. It was maintained that abortion had many immediate and long-term negative effects; it could result in problems in subsequent pregnancies and above all cause infertility. The negative effects were demonstrated in follow-up studies that were carried out after the legalisation of abortion in 1957. Abortions were estimated by Czechoslovak experts as having negative consequences (including those less serious) in between $15 \%$ and $70 \%$ of cases, of which infertility accounted for between 1.3\% and 7.4\% of cases [Kotásek 1976: 32]. The Memorandum accompanying the bill of 1986 cited $20-30 \%$ of cases in which induced abortion had negative consequences (Part 1 of the Memorandum to Act No. 66/1986 Coll.).

Since 1957 the fact of having an abortion was automatically linked to the risk of not being able to have other children [e.g. Houdek 1973]. In the 1980s, authors believed the risk to be lower, especially when mini-abortion method was used, but it was still emphasised that every abortion presented a risk. Even today, the argument of the risk of subsequent infertility is widely used by the opponents of free choice and makes part of a widely shared belief in the Czech Republic.

The discourse of the dangers of abortion was developed and used mainly by conservatively-oriented experts (presumably from a Catholic background) such as Alfred Kotásek [Kotásek and Fuchs 1976]. Their argumentation proved counter-productive for them in the 1981-1986 discussions, as they could not object to the effort to perform as many abortions as possible using the method of early vacuum-extraction, given that this method was proved to have fewer negative consequences for the reproductive health of women.

Any frames articulated by feminists or women themselves did not appear openly in the press or scientific journals. Nonetheless, we have reason to assume that among women themselves the opinion that a 'woman has the right to make decisions about her own pregnancy' started to gain in significance. Women were frustrated by having to expose private matters in front of members of the abortion commission (who were sometimes also their neighbours, employers, former teachers, etc.): 'I was in front of an abortion commission once and I do not want to have to go through it ever again. ... It is appalling to have to explain and confide such sensitive problems to complete strangers', said a reader named J. Š. on the pages of Vlasta in 1969 [J.Š. 1969].

Some of the experts who fought for the liberalisation of abortion legislation (e.g. Jiři Šráček, Radim Uzel, Jiřina Fukalová) held the opinion that it should be the right of the woman herself to decide whether or not to have an abortion and nobody else. Still, when criticising the existence of the abortion commissions, the 
arguments Jiř́ Šráček and his colleagues used in the press were primarily medical. Only in an article in Vlasta in 1984 did he depart slightly from medical argumentation by stating that the health risks presented by an abortion for a woman are in fact much smaller than the risks connected with pregnancy and childbirth, and 'if she does not want to undergo such risks, I maintain that nobody has the right to force her to do so' (an interview with Jiří Šráček in Štěpánková [1984]).

Interestingly, a shift in the discourse can be observed in the Memorandum that accompanied the bill of 1986 and the transcripts of the parliamentary debate over it. While in the expert and popular articles dating from the period preceding the approval of the law there are few remarks that touch on a woman's right to choose, in the official text of the law and its Memorandum we find many direct references to women's reproductive rights. For example: 'The bill is establishing a new principle that respects a woman's will, whether to end her pregnancy by birth or by induced abortion. The bill gives a woman the right to terminate her pregnancy, and the woman does not have to justify her request'. (Special Part, K §4 in the Memorandum to Act No. 66/1986 Coll.) During the process of preparing the text of the legislation, some of its authors accentuated the frame of a woman's right to choose and surprisingly even favoured this frame in their arguments and explanations of the content of the bill. We can only guess what exactly lay behind this shift in the discourse. First, it may have been a resurgence of the Marxist tradition that originally framed abortion as a woman's right. This frame must have been familiar to women politicians, who had undoubtedly read the work of Marx and Engels. Another hypothesis is that it resulted from the migration of ideas, as the borders were not as tightly shut in the 1980s as in previous periods. Some ideas from the women's movement could have slipped through and found resonance among certain actors. Nevertheless, the third hypothesis is probably the most plausible one: it was women themselves who developed the new discourse. Many of them had had some form of unpleasant experience with the abortion commissions' proceedings, while all of them were almost solely responsible for childcare and household chores in their own lives and the same time were empowered by the economic independence they derived from full-time employment. The frame of a 'woman's right to choose' finally made its way to Parliament and was interpreted in a way that chimed with contemporary ideology. Nevertheless, it was not reflected in the media discourse, which remained dominated by experts who stuck to the medical abortion frames.

\section{The debates after 1989}

Since 1989, with the emergence of civil society and democratic discussion, new debates on abortion surfaced. Space opened up not just for constructing/framing abortion in feminist discourse as a basic right for women, but also for the rejection of abortion on moral and religious grounds and the renewal of attempts to dispossess women of this right. 
In 1991, a group of experts headed by Jiř́ Šráček started to work on a new wording of the abortion law. These experts were dissatisfied with some features of the 1986 act. They saw this as an opportunity to correct shortcomings in the act that were caused partly by the lack of democratic discussion in the period when the legislation was being prepared. Nevertheless, this new bill (expanding the right to abortion) was never submitted to the Government. According to my informant, Dr. Jiří Śráček, the then Prime Minister Václav Klaus called the Minister of Health Petr Lom and instructed him not to submit the law. ${ }^{10}$

Already in 1991-1993, the authors of the unsuccessful law proposal were aware of the possible influence that the Roman Catholic Church and the political representatives of Christian Democrat party KDU-ČSL might exercise on the abortion issue. Although KDU-ČSL repeatedly obtained a low share of votes in post-1989 democratic elections (6-9\%), in the 1992-1998 and 2002-2009 periods the party was part of the government coalitions and thus represented a serious political power. In 2003, several Members of Parliament (Christian-Democrats Jiří Karas and Jan Kasal, and right-wing Petr Pleva) proposed a law that would make abortion illegal. A large debate followed in the media, with major participation from women's and feminist groups, who claimed abortion as a basic human right. The bill was rejected in the first reading.

A similar situation occurred in 2008, when David Macek, the vice chair of KDU-ČSL announced in the media his party's intention to make the abortion law more restrictive. Party representatives did not, however, undertake any political action aimed at changing the status quo. They did not address their demands to the Minister of Health and they confined themselves to opposing any kind of liberalisation that might be introduced as part of the health reform being prepared by the Minister of Health Tomáš Julínek. ${ }^{11}$

\section{The frame used by anti-pro-choice actors}

The main arguments employed by Catholic-oriented MPs in the Parliamentary debate and in presentations of their position in the media reflected the Catholic Church's official stance; sometimes they were underpinned by a 'scientific approach' to embryonic development. They did not significantly differ from the an-

\footnotetext{
10 This decision might have been the result of a coalition deal between the ruling ODS (Civic Democratic Party) and the coalition Christian-Democratic Party KDU-ČSL, headed at that time by Josef Lux.

${ }^{11}$ In the bill on Specific Health Services, there were two points that in practice would mean a widening of access to abortion. First, the parents (or carers) of girls aged between 16 and 18 years would not have to be informed about an abortion. Second and most importantly, abortion on demand would also be accessible to foreigners who do not have the status of permanent resident in the Czech Republic (draft bill on Specific Health Services, paragraph 11. 11. 4.).
} 
ti-abortion arguments used in debates in other countries. The arguments they used concerning women's motivations and decisions deserve more attention here.

In these anti-pro-choice arguments the woman is portrayed as irresponsible, unable to decide for herself, fragile and manipulated by others. She is first and foremost a mother - an abortion could prevent her from being a mother in the future - and given the choice and the ideal conditions she would always choose to have the child: 'And also it is very common for pregnant women to pay a high price for the abortion - she never experiences the joy of motherhood. And in many cases, she deeply regrets her decision, often made under pressure.' (MP Jiří Karas, debate in the Chamber of Deputies on 26 March 2004, 14:50) If a woman requests an abortion for 'selfish reasons', such as not wanting to compromise her career by having a child, her choice is ethically invalid. But as a mother she is assigned a passive role - that of a vessel carrying a child that is perfect and almost independent from the very beginning, or that of an educator, accepting the child unconditionally and regardless of its health or mental state.

These arguments thus build on the abortion frames of the communist period, identifying women as mothers and questioning their ability to decide and the legitimacy of their decision, and doing so using medical arguments about the risk of infertility.

\section{The frames of women's and feminist groups}

Czech feminist NGOs, in particular Gender Studies o.p.s., reacted quickly to the proposed restrictive legislation of 2003. The activists started lobbying and making presentations in the media. In a very short time, they prepared a statement that was disseminated via the internet and published on the pages of the main Czech newspapers. ${ }^{12}$

Surprisingly, the text of the statement did not use any feminist arguments. It pointed out the risks of making abortion illegal (the health risks of illegal abortions, high prices) and the fact that abortion would not disappear even if it were prohibited. The authors also showed that the prohibition of abortions would not lead to a higher fertility rate, and noted that the abortion rate had decreased sharply in the previous ten years. They suggested alternative solutions: educating the young generation on reproductive rights and responsibilities and introducing effective policies of family support and work-life balance policies.

The absence of a feminist frame and women's rights terminology in the petition can be explained as part of the general 'discursive strategy' employed women's and feminist groups in the Czech Republic. The success of their lobbying is (at least in the eyes of most activists) dependent on the strategic use of some socially sensitive terms, and above all the term 'feminism' had to disappear from

${ }^{12}$ See http://www.feminismus.cz/fulltext.shtml?x=162657. 
its vocabulary [see Vodrážka 2009; Vodrážka 2006: 62-65]. Activists prefer to use more neutral words, such as 'equal opportunities' and 'gender mainstreaming' (instead of women's rights or feminism).

There are two reasons for the discrediting of feminist terminology in Czech public discourse. First, some terms were abused during the communist regime. The use of women's issues during the communist period and the Marxist-Leninist approach to women's equality turned 'women's emancipation', 'women's equality', and the 'women's movement' into pejorative concepts for the Czech public [Heitlinger 1996: 82]. 'Anything to do with women's emancipation was negatively associated with the discredited old regime and this association extended to feminism, seen as just another -ism.' [Waylen 2007: 81]

The second reason for the discrediting of feminism and the women's movement was the way in which Western feminism was presented by the Czech media in the first half of the 1990s. Articles that appeared, for example, in Respekt (a prestigious weekly magazine) introduced the feminist movement as a foreign (American) ideology that distorts the relationship between men and women [see Jedličková 2006: 106-107].

The organisations that defined themselves overtly as 'feminist' on their website or in personal contact then chose deliberately to avoid using the term or directly referred to specific women's claims when they entered the public discourse. This strategic naming game is even more accentuated in the case of the abortion issue, where the vocabulary is extremely sensitive. The fear of using any kind of overtly feminist arguments is palpable in the text of the statement. Not even the word 'woman' was used in the text. As Linda Sokačová, one of the authors of the petition, explained to me in an interview: 'We really pay attention to the vocabulary - we try to formulate things in a way that is acceptable to everybody. Why use the word "feminism", if you can put through a feminist idea without it? The proclamation in 2004 had a special purpose, very neutral vocabulary. We were careful that nobody could say that we promote abortions.'

It is necessary to note here that this 'utilitarian' framing of abortion in mostly medical terms is not specific to the Czech Republic /Czechoslovakia and has been used by advocates of a woman's right to abortion in other countries (including democratic ones), such as Italy or the UK, where the conflicts and controversies surrounding abortion right resulted in similar terms of debate those seen under state socialism in the Czech Republic, with pro-choice advocates similarly using medicalised language and rationales to justify the liberalisation of abortion [see, e.g., Francome 1984: 83-85; Calloni 2001: 186]. But unlike in Czechoslovakia, this frame was accompanied by the claim of the 'right of women to control their bodies and their fertility' [McBride Stetson 2001: 140].

The very fact that abortion was not criminalised in Czech Republic in the post-communist period (unlike Poland) suggests the greater relative power of pro-choice groups in this country and the greater public resonance of their framing. This reveals the political utility of framing abortion in medical terms as a 
woman's health issue, in order to avoid the morally controversial discussion of the 'beginning of human life' or the 'rights of unborn children'. The framing of abortion in medical terms helped to attain goals similar to those of the pro-choice actors and groups, but it may also have presented some risks. Strikingly, in the state-socialist period, the medical frame was also used by the opponents of women's free choice, pointing to the health risks of abortion and the resulting need to control the number of abortions granted.

The secular political elites in the post-socialist period also found the medical frame appealing. Given the controversial nature of the issue and the difficulty of obtaining a democratic compromise, pragmatic politicians usually prefer not to open the debate at all. 'In a parliamentary system which is dependent on coalition cabinets to govern, abortion is too disruptive issue to keep recurring on the agenda. Because it cuts across the prevailing left-right spectrum, it makes for continual tension in the inevitable negotiations and compromises required for coalition rule.' [Outshoorn 2001: 220] Hence the current abortion legislation in the Czech Republic is essentially the same as the legislation adopted in 1986.

This continuity of framing might be useful for most of the 'progressive' actors, but it has some serious pitfalls, especially in connection with the need to extend rights and entitlements to groups who were previously excluded.

\section{The limits of the medical frame: the case of abortion denied to 'foreign' women}

The limits of framing of abortion as a medical (and psychological) issue and the persistence of this framing in the Czech public discourse of abortion became manifest in the most recent abortion debate in 2008. This debate concerned (among others) the prohibition of abortion for any woman without long-term residence status. Since 1973 abortion cannot be granted to citizens of other countries who are not long-term residents of Czechoslovakia.

The prohibition of abortion for foreign women only temporarily residing in the Czech Republic is an example of the path dependency of institutions. It was introduced in 1973 as part of broader measures aimed at limiting access to abortions (connected with 'Normalisation' processes) and combating 'abortion tourism' from Western European countries. It was kept in the new act of 1986 and it survived the tumultuous years that followed November 1989. The legislation proposed in 1993 tried to get rid of this measure but did not attain agenda-status. In the following years, every attempt to extend access to abortion was undermined from the start by the small, yet politically important Christian Democratic Party. In consequence, certain migrants (those with short-term visas or without documents) do not have access to abortion.

In the spring of 2008, the Minister of Health, Tomáš Julínek, submitted a proposal for overall health reform. In this proposal, an act on specific health services stated that the abortion on demand should also be made accessible to 
foreigners without the status of permanent resident in the Czech Republic. The Memorandum to this proposed legislation explains that 'all women should have the same access to abortion services' (here the frame of abortion as a woman's right is used).

This change in the law meant a widening of the right to abortion and it encountered strong criticism from conservative representatives of the Christian Democratic Party. Their protests put the success of the entire reform proposal at risk and the Minister had to moderate his demands. Still, he (and his speakers) argued that it is inevitable that access to abortion be open to all EU citizens, regardless of their residency status in the Czech Republic. Instead of the frame of women's reproductive rights, the issue was now presented as a part of the process of harmonising Czech legislation with that of the EU, as all women in the European Union must have the same access to health care in every member country: '...there is an agreement that at the Government level we cannot allow ourselves to directly declare a violation of the primary law of the $\mathrm{e}^{\prime 13}$ [Julínek quoted in iDnes. $c z 19$ November 2008]. The representatives of KDU-ČSL did not accept this logic and continued to oppose the reform proposal.

The Health Reform Bill designed by Tomáš Julínek was never submitted to Parliament, as after lengthy negotiations the Government was dissolved in the spring 2009. Access to abortion is consequently still limited to women with a permanent or long-term residence permit in the Czech Republic. Nevertheless, the 2008 discussions opened a new horizon on the abortion debates, the context of the European Union, and we can assume that this argument will be used again in the future, with the possible outcome of widening bodily citizenship to all women on Czech territory. What is striking in these circumstances is the fact that the 2008 debates were not monitored by any of the non-governmental organisations interested in the rights of (women) migrants or any women's movement organisations, which might have attempted to reframe the issue.

The main problem thus stems from the fact that the induced termination of pregnancy in the Czech context has never been framed and interpreted in terms of human or women's rights or as a part of bodily citizenship, but only as a medical, demographic or psychological problem. In consequence, it is almost impossible to open up space to discuss abortion in connection to the rights of women living temporarily on the territory of Czech Republic.

\footnotetext{
${ }^{13}$ See Barbora Němcová. 2008. 'Vláda schválila zákony k reformě zdravotnictví, odložila úpravu pojištění.' (The Government Passed Legislation on Health Reform, Postponement the Insurance Amendment) iDnes, 19 November. Retrieved 17 December 2010 (http://zpravy. idnes.cz/vlada-schvalila-zakony-k-reforme-zdravotnictvi-odlozila-upravu-pojisteni-1uj/domaci.asp?c=A081119_111355_domaci_ban).
} 


\section{Conclusion}

In the public discussion preceding the approval of the first Czechoslovak abortion law in 1957, mainly medical arguments were used - legal abortion was framed as a way to 'healthier motherhood'. The persistent monopoly of medical experts over the argumentation on the abortion issue was also manifest in the debates preceding the law of 1986 that resulted in further liberalisation.

Since 1989, when space for civil society and democratic discussion opened up, the Czech Republic has witnessed emerging new debates about abortion. While some conservative groups came out with attempts to make the abortion legislation more restrictive, newly formed women's and feminist groups claimed abortion as a basic human right. Still, even these actors preferred to use medical and psychological arguments when addressing the general public.

In fact, since the 1950s abortion had been constructed as a medical issue. Pre-war feminist groups were dismantled and were unable to play any significant the role in the abortion issue. This role was taken over by gynaecologists who were since the 1950s the most important actors in the abortion debates in Czechoslovakia / the Czech Republic. They spoke from a position of authority and knowledge, while women asking for abortion were to be judged, educated and helped.

The medicalised discourse of abortion helped fabricate a specific knowledge of abortion, a specific truth that now in the Czech context is taken for granted. The right of every woman to choose freely or make decisions about her own body is not really part of this knowledge. Abortion is primarily defined as a health issue, not a human rights issue or a political one.

This knowledge is intrinsically linked to power. First, power relations were present at the moment of the constitution of the knowledge within the discourse of abortion, in the form of mechanisms and expert instances producing and sanctioning truth. Second, the knowledge of abortion is mirrored in the discursive power of language reflecting and shaping the social order, present, for example, in people's points of view and value systems, determining who should have access to abortion or not and under which conditions, and also what the 'inevitable' consequences of an abortion are. This socially constituted 'truth' then hinders the possibility of reframing the abortion in terms of women's reproductive rights, as is reflected in the fact that the current Czech legislation on abortion has proved impossible to amend.

The persistence of this framing in the abortion discourse has an impact on the possibilities for changing institutions. According to the theories of discursive institutionalism, institutions change because discourses (or ideas) change. In the former Czechoslovakia, the institutions changed - first in 1957, then in 1986 - while the dominant discourse remained almost the same. The medical framing of abortion, the accent put on the health of women-mothers, combined with the focus on the quality and quantity of the population, still prevails. In the past, change came from the outside, as the result of altered external circumstances. 
While in 1957 the law changed mainly owing to pressure from Soviet authorities, in 1986 it was owing to two important findings of scientific research (the research on the early vacuum extraction method of abortion and the technical developments that went with it; and the research on the consequences of unwanted pregnancies). The way the issue was framed (in terms of protecting women's health) did not change, but new arguments were added (e.g. the harmlessness of early abortions), and the outcomes were suddenly dramatically different.

In the current situation, this discursive framing serves to obstruct further change. On the one hand, organised religion and 'pro-life' groups have largely failed in their attempts to impose their framing on the public discourse (and legislation on abortion) because of the strong secularism in Czech culture and the resonance of medical discourse in the public opinion. On the other hand, efforts to further liberalise abortion institutions proved equally impossible. This became manifest in the discussion in late 2008 about extending the right to abortion to 'foreigners' who have no long-term residence status in the Czech Republic. Given that abortion in the Czech context has never been framed and interpreted in terms of human or women's rights, it proved impossible to widen the discussion about abortion to encompass the rights of women - in this case, women living temporarily on the territory of the Czech Republic.

It has proved very difficult to re-frame abortion as a human right of all women. Czech women's movements are aware that the feminist framing finds does not resonate with the frames of policymakers or participants, so they reformulate their arguments to conform to the dominant discourse and do not attempt to re-frame the issue. In consequence, they are unable to push the agenda forward and settle for maintaining the status quo.

Consequently, the abortion discourse in the Czech Republic is a good example of the perseverance and continuity of power/knowledge discourse and its influence on the path-dependency of institutions. The life of the institutions and discourses is strongly interlaced. The question is what conditions and what kind of actors it would take to cause this complex to change.

RADKA DuDOvá is a researcher at the Institute of Sociology of the Academy of Sciences of the Czech Republic. Her work focuses on the transformations of intimate life and the family in the context of the changes to work and the labour market. She is the author of the book Fatherhood after Marital Separation (Otcovstvi po rozchodu rodičovského páru; Praha: Sociologicky ustav AV ČR, v.v.i., 2008). Since 2009 she has been a post-doctoral researcher at Leiden University in the Netherlands, where she studies the bodily citizenship of women in the Czech Republic and Europe, specifically with regard to abortion and prostitution. 


\section{References}

Birgus, Jan. 1979. 'Několik připomínek porodníka k problému nechtěných těhotenství.' (Several Comments from an Obstetrician on the Issue of Unwanted Pregnancy) Československá gynekologie 44 (1): 69-76.

Buckley, Mary. 1989. Women and Ideology in the Soviet Union. Ann Arbor: University of Michigan Press.

Calloni, Maria. 2001. 'Debates and Controversies on Abortion in Italy.' Pp. 181-204 in Abortion Politics, Women's Movements, and the Democratic State, edited by D. McBride Stetson. New York: Oxford.

David, Henry, Zdeněk Dytrych and Zdeněk Matějček. 2003. ‘Jaké šance na úspěch mají nechtěné děti?' (What Chances of Success Do Unwanted Children Have?) Psychologie dnes (9): 28-30.

Donati, Paolo R. 1992. ‘Political Discourse Analysis.' Pp. 136-167 in Studying Collective Action, edited by M. Diani and R. Eyerman. London: Sage.

Dytrych, Zdeněk, Zdeněk Matějček and Vratislav Schüller. 1975. Nechtěné děti: Závěrečná zpráva dílčího úkolu st. plánu badatelského výzkumu čís. VII-3-7/2.2. (Unwanted Children: Final Report on the Sub-assignment of Research Plan No. VIII-3-7/2.2) Prague: Výzkumný ústav psychiatrický.

Dytrych, Zdeněk, Zdeněk Matějček, Vratislav Schuller, Henry P. David and Herbert L. Friedman. 1975. 'Children Born to Women Denied Abortion.' Family Planning Perspectives 7 (4): 165-171.

Entman, Robert M. 1993. 'Framing: Toward Clarification of a Fractured Paradigm.' Journal of Communication 43 (4): 51-58.

Fairclough, Norman. 1992. Critical Language Awareness. London: Longman.

Fidelis, Malgorzata. 2008. "“A Nation's Strength Lies Not in Numbers." De-Stalinisation, Pronatalism and the Abortion Law of 1956 in Poland.' Pp. 203-216 in

Geschlechterbeziehungen in Ostmitteleuropa nach dem zweiten Weltkrieg: Soziale Praxis und Konstruktionen von Geschlechterbildern, edited by C. Kraft. Oldenbourg: Oldenbourg Wissenschaftsverlag.

Foucault, Michel. 1961. Folie et déraison. Histoire de la folie à l'âge classique. Paris: Plon.

Foucault, Michel. 1963. Naissance de la clinique - une archéologie du regard médical. Paris: PUF.

Foucault, Michel. 1980. Power / Knowledge: Selected Interviews and Other Writings, 1972-1977. New York: Pantheon.

Foucault, Michel. 1994 [1971]. Diskurz, autor, genealogie. (Discourse, the Author, Geneology) Compilation in Czech of L'Ordre du discourse, Qu'est-ce qu'un auteur, Nietzsche, la généalogie, l'histoire. Prague: Svoboda.

Foucault, Michel. 2004 [1975]. Surveiller et Punir. Paris: Gallimard.

Francome, Colin. 1984. Abortion Freedom. Winchester: George Allen and Unwin.

Fukalová, Drahomíra. 1979. 'Znovu k problematice interrupčních komisí.' (Revisiting the Issue of Abortion Commissions) Československá gynekologie 44 (10): 752-754.

Fukalová, Drahomíra. 1981. 'Přednosti regulace menstruace z psychologického hlediska.' (The Psychological Advantages of Menstrual Regulation) Ceskoslovenská gynekologie 46 (6): 490-492.

Fuszara, Małgorzata. 2005. 'Between Feminism and the Catholic Church: The Women's Movement in Poland.' Sociologický časopis/Czech Sociological Review 41 (6): 1057-1075.

Hamplová, Dana. 2010. 'Are Czechs the Least Religious of All?' The Guardian, 24 June. Retrieved 24 June 2010 (http://www.guardian.co.uk/).

Havránek, F. 1981. 'Význam mini-interrupce (regulace menstruace) jako metody regulace porodnosti.' (The Significance of Mini-Abortions (Menstrual Regulation) as a Method of Birth Regulation) Československá gynekologie 46 (6): 481-485. 
Heinen, Jacqueline and Anna Matuchniak-Krasuska. 1995. 'Abortion in Poland: A Vicious Circle or a Good Use of Rhetoric.' Women's Studies International Forum 18 (1): 27-33.

Heinen, Jacqueline and Stephan Portet. 2010. 'Reproductive Rights in Poland: When Politicians Fear the Wrath of the Church.' Third World Quarterly 31 (6): 1007-1021.

Heitlinger, Alena. 1984. Reproduction, Medicine and the Socialist State. London: Macmillan Press.

Heitlinger, Alena. 1996. 'Framing Feminism in Post-Communist Czech Republic.' Communist and Post-Communist Studies 29 (1): 77-93.

Hnátek, L. 1957. 'O slovo se hlásí ženský lékař.' (A Woman Doctor Takes the Floor) Literární Noviny 6: 9.

Houdek, Jiří. 1973. 'Rodičům do notesu: znalosti o antikoncepci.' (A Note to Parents: Knowledge on Contraception) Vlasta 27 (29): 19.

Hrádek, D. and J. Petr. 1981. 'Příspěvek k diskusi na téma "problematika činnosti interrupčních komisí".' (A Contribution to the Discussion on the Theme of the 'Issue of the Work of the Abortions Commissions') Československá gynekologie 46 (6): 497.

J.Š. 1969. 'K anketě o interrupcích.' (On the Survey on Abortions) Vlasta 23 (42): 24.

Jechová, K. 2008. 'Cesta k emancipaci. Postavení ženy v České společnosti 20. století. Pokus o vymezení problému.' (The Road to Emancipation: The Position of Women in Czech Society in the 20th Century) Pp. 69-129 in Pět studií k dějinám české společnosti po roce 1945, edited by O. Tůma and T. Vilímek. Prague: Ústav pro soudobé dějiny AV ČR.

Jedličková, Petra. 2006. 'Nevidět, neslyšet a nedotýkat se! Feminismus jako součást demokratizačního procesu v ČR v letech 1989-2004 - reflexe médií.' (Here, See, and Touch Nothing! Feminism as Part of the Democratisatoin Process in the Czech Republic in 1989-2004 - as Reflected in the Media) Pp. 103-118 in Mnohohlasem. Vyjednávání ženských prostorů po roce 1989, edited by H. Hašková, A. Křižková and M. Linková. Prague: Sociologický ústav AV ČR.

Kalinová, L. 1999. K sociálním dějinám Československa v letech 1969-1989. (A Social History of Czechoslovakia 1969-1989) Prague: VŠE.

Kotásek, Alfred and Vladimír Fuchs. 1976. 'Umělé přerušení těhotenství a morbidita žen.' (Induced Abortion and Female Morbidity) Československá gynekologie 41 (1): 31-33.

Kulawik, Teresa. 2009. 'Staking the Frame of a Feminist Discursive Institutionalism.' Politics and Gender 5 (2): 262-271.

Lister, Ruth. 1997. Citizeship. Feminist Perspectives. London: Macmillan Press.

McBride Stetson, Dorothy. 2001. 'Women's Movements' Defence of Legal Abortion in Great Britain.' Pp. 135-156 in Abortion Politics, Women's Movements, and the Democratic State, edited by D. McBride Stetson. New York: Oxford.

Mehan, Hugh. 1999. 'Oracular Reasoning in a Psychiatric Exam.' Pp. 559-575 in The Discourse Reader, edited by A. Jaworski and N. Coupland. London: Routledge.

Mikule, Vladimír. 1957. 'Hovoříme o společenských vztazích.' (Let's Talk about Social Ties) Literární noviny 6 (32): 9.

Molyneux, Maxine. 1981. 'Socialist Societies Old and New: Progress Towards Women's Emancipation.' Feminist Review (8): 1-34.

Mureşan, Cornelia. 2008. 'Impact of Induced Abortion on Fertility in Romania.' European Journal of Population 24: 425-446.

'Na závěr diskuse.' (To Conclude the Discussion) 1957. Literární noviny 6 (38): 9.

Němcová, Barbora. 2008. 'Vláda schválila zákony k reformě zdravotnictví, odložila úpravu pojištění.' (The Government Passed Legislation on Health Reform, Postponement the Insurance Amendment) iDnes, 19 November. Retrieved 
17 December 2010 (http://zpravy.idnes.cz/vlada-schvalila-zakony-k-reformezdravotnictvi-odlozila-upravu-pojisteni-1uj-/domaci.asp?c=A081119_111355_domaci_ ban).

Outshoorn, Joyce. 2001. 'Policy-making on Abortion: Arenas, Actors and Arguments in the Netherlands.' Pp. 205-228 in Abortion Politics, Women's Movements, and the Democratic State, edited by D. McBride Stetson. New York: Oxford.

Peters, B. Guy, Pierre Jon and Desmond S. King. 2005. 'The Politics of Path Dependency: Political Conflict in Historical Institutionalism.' The Journal of Politics 67 (4): 1275-1300.

Radvanová, Senta, Jiří Nezkusil and Oto Novotný. 1957. 'Pro zdraví žen.' (For Women's Health) Literární Noviny 6: 9.

Rothstein, Bo. 2005. Social Traps and the Problem of Trust. Cambridge: Cambridge University Press.

Schmidt, Vivien A. 2010. 'Taking Ideas and Discourse Seriously: Explaining Change through Discursive Institutionalism as the Fourth "New Institutionalism".' European Political Science Review 2 (1): 1-25.

Schneck, Stephen Frederick. 1987. 'Michel Foucault on Power/Discourse, Theory and Practice.' Human Studies (10): 15-33.

Slunský, Rudolf. 1957. 'Proč škodí potrat?' (Why Is Abortion Harmful?) Vlasta 11 (11): 6.

Snow, David A. and Robert D. Benford. 1988. 'Ideology, Frame Resonance, and Participant Mobilisation.' Pp. 197-217 in From Structure to Action: Comparing Social Movement Research across Cultures, edited by B. Klandermans, H. Kriesi and S. Tarrow. London: Jai Press, Inc.

Štěpán, J. 1981a. 'K právním aspektům výzkumu a praxe na úseku porodnosti.' (On the Legal Aspects of Research and Practice on Natality) Československá gynekologie 46 (6): 493-495.

Štěpán, J. 1981b. 'Právní aspekty výzkumu a praxe na úseku regulace porodnosti.' (On the Legal Aspects of Research and Practice on Natality Regulation) Československá gynekologie 46 (3): 213-216.

Štěpánek, Jiř́i. 1957. 'Hovoříme o společenských vztazích.' (Let's Talk about Social Ties) Literární noviny 6 (31): 9.

Štěpánková, Zdena. 1984. 'Antikoncepce - ano či ne.' (Birth Control: Yes or No) Vlasta 38 (5): 10.

Tučková, Anna. 1957. 'A láska nenarodí se?' (And Is Love Not Born?) Vlasta 11 (38): 12.

ÚZIS (Ústav zdravotnických informací a statistiky ČR). 2008. Potraty (2007). (Abortion 2007) Prague: Ústav zdravotnických informací a statistiky ČR.

van Dijk, Teun A. 1993. 'Discourse and Cognition in Society.' Pp. 107-126 in Communication Theory Today, edited by D. Crowley and D. Mitchell. Oxford: Pergamon Press.

van Leeuwen, Theo. 1993. 'Genre and Field in Critical Discourse Analysis.' Discourse and Society 4 (2): 193-225.

Vodrážka, Mirek. 2006. 'Aktivismus bez hnutí nebo protohnutí? Ženské organizace a skupiny v ČR v letech 1989-2006.' (Activism without a Movement or Proto-Movement? Women's Organisations and Groups in the Czech Republic in 1989-2006) Pp. 61-80 in Mnohohlasem. Vyjednávání ženských prostorů po roce 1989, edited by H. Hašková, A. Kř́žzová and M. Linková. Prague: Sociologický ústav AV ČR.

Vodrážka, Mirek. 2009. 'Je na překážku, když se gender spojuje pouze se ženami...' (Linking Gender Just to Women Is a Setback) Prague: Gita - Genderová informační a tisková agentura. Retrieved 10 September 2009 (http://www.ta-gita.cz/ kriticke-reflexe/je-na-prekazku-kdyz-se-gender-spojuje-pouze-se-zenami/).

Vojta, Miroslav. 1957. 'Nechtěné mateřství.' (Unwanted Motherhood) Vlasta 11 (40): 12. 
Vojta, Miroslav. 1961. 'Nový význam potratů a přerušení těhotenství pro populační vývoj.' (The New Significance of Abortion and Pregnancy Termination for Population Development) Pp. 159-177 in Demografický sborník 1961. Prague: State Statistical Office.

Waylen, Georgina. 2007. Engendering Transitions. Women's Mobilisation, Institutions, and Gender Outcomes. Oxford: Oxford University Press.

Wolchik, Sharon L. 2000. 'Reproductive Policies in the Czech and Slovak Republic.' Pp. 58-91 in Reproducing Gender: Politics, Publics, and Everyday Life after Socialism, edited by S. Gal and G. Kligman. New Jersey: Princetown University.

Zajíček, Karel. 1973. 'Přes sto tisíc zmařených životů. Jaké změny v povolování interrupcí?' (More Than a Hundred Thousand Wasted Lives: Changes to Granting Abortions) Vlasta 29 (19): 20. 